\title{
The Effects of Dopants and A:B Site Nonstoichiometry on Properties of Perovskite-Type Proton Conductors
}

\author{
J. Guan, ${ }^{* a, a b}$ S. E. Dorris, ${ }^{\circ}$ U. Balachandran, and M. Liu**,b \\ ${ }^{a}$ Argonne National Laboratory, Energy Technology Division, Argonne, Illinois 60439, USA \\ ${ }^{b}$ School of Materials Science and Engineering, Georgia Institute of Technology, Atlanta, Georgia 30332, USA
}

\section{ABSTRACT}

Investigations of perovskite-type $\mathrm{BaCeO}_{3}$ and $\mathrm{SrCeO}_{3}$ with various dopants $(\mathrm{Y}, \mathrm{Gd}, \mathrm{Nd}$, and $\mathrm{Ni}$ ) indicate that their microstructures and electrical properties are strongly influenced by the type and amount of dopants. Grain growth and densification of sintered samples are influenced by dopant level and $A: B$ site nonstoichiometry. The conductivity of $\mathrm{BaCe}_{1-x} \mathrm{Y}_{x} \mathrm{O}_{3-\delta}$ increases with the yttrium content in hydrogen and wet Ar, and exhibits a maximum in oxygen at an yttrium content of 10 to $20 \%$. $\mathrm{BaCe}_{0.8} \mathrm{Y}_{02} \mathrm{O}_{3-\delta}$ has the highest conductivity in a hydrogen atmosphere: $\sim 1.54 \times 10^{-2} \Omega^{-1} \mathrm{~cm}^{-1}$ at $600^{\circ} \mathrm{C}$, and $-4.16 \times 10^{-2} \Omega^{-1} \mathrm{~cm}^{-1}$ at $800^{\circ} \mathrm{C}$. The effect of $\mathrm{BaO}$ excess depends on the concentration of dopant. Compared with $\mathrm{BaCe}_{0.95} \mathrm{Y}_{0.05} \mathrm{O}_{3-\delta}$, doped $\mathrm{BaCeO}_{3}$ with $\mathrm{BaO}$ excess $\left(\mathrm{BaO} \cdot 0.90 \mathrm{CeO}_{2} \cdot 0.025 \mathrm{Y}_{2} \mathrm{O}_{3}\right)$ has a higher total conductivity in all atmospheres studied $\left(\mathrm{O}_{2}, \mathrm{H}_{2}\right.$, and wet $\left.\mathrm{Ar}\right)$, whereas the conductivity of $\mathrm{BaCeO}_{3}$ with excess $\mathrm{BaO}\left(\mathrm{BaO} \cdot 0.85 \mathrm{CeO} \cdot 0.05 \mathrm{Y}_{2} \mathrm{O}_{3}\right)$ is lower than that of $\mathrm{BaCe}_{0.9} \mathrm{Y}_{0.1} \mathrm{O}_{3-\delta}$. $\mathrm{BaCeO}_{3}$ based materials have higher conductivities than those of $\mathrm{SrCeO}_{3}$ based materials, whereas $\mathrm{SrCeO}_{3}$ based materials show higher proton transference numbers.

\section{Introduction}

Mixed ionic electronic conductors (MIECs) are used in many solid-state electrochemical systems such as solid oxide fuel cells (SOFCs), solid-state gas sensors, and membranes for gas separation., ${ }^{1,2}$ Two well-known MIECs are the partially substituted perovskite-type oxides $\mathrm{BaCeO}_{3}$ and $\mathrm{SrCeO}_{3}$, in which substitution for Ce by trivalent cations causes the formation of oxygen vacancies and other charged defects and gives rise to mixed conduction in atmospheres containing $\mathrm{O}_{2}, \mathrm{H}_{2}$, and $\mathrm{H}_{2} \mathrm{O}$ vapor. Because much of the charge transport in $\mathrm{BaCeO}_{3}$ and $\mathrm{SrCeO}_{3}$ is by protons, these materials are being investigated as possible hydrogen separation membranes. To be suitable for hydrogen separation, a material must have a high selectivity for hydrogen, so its proton transference number must be much higher than its transference number for oxygen ion conduction. To be useful in a nongalvanic mode, the transference number for electronic conduction should be comparable to that for protonic conduction, and the protonic and electronic conductivities should be sufficiently high (> $-5 \times 10^{-2} \Omega^{-1} \mathrm{~cm}^{-1}$ ). In addition, the materials must exhibit high catalytic activity for the dissociation and recombination of hydrogen at the gas/solid interfaces.

Transport properties of perovskites are strongly influenced by the ionic radii of dopants. Kilner and Brook ${ }^{3}$ used lattice simulation techniques to model ionic conduction in perovskites and concluded that the overall activation energy for conduction should be minimal when the host and dopant cations have similar ionic radii. Based on this criterion, Bonanos et al. suggested that $\mathrm{Gd}$ would maximize the conductivity of $\mathrm{BaCeO}_{3 .}{ }^{4}$ In fact, $\mathrm{BaCe}_{0.8} \mathrm{Gd}_{0.2} \mathrm{O}_{3-\delta}$ has been widely studied for SOFCs because of its high conductivity in $\mathrm{O}_{2}$-containing atmospheres and under fuel cell conditions. ${ }^{4-6}$ Iwahara et al. ${ }^{7}$ studied the mixed conduction of $\mathrm{Yb}-$, Y-, Dy-, Gd-, Sm-, and $\mathrm{Nd}-$ doped $\mathrm{BaCeO}_{3}$, and reported that the proton transference number decreased while the oxygen ion transference number increased with increasing dopant ionic radius. They reasoned that dopants with large ionic radii made oxygen ion conduction more favorable by enlarging the spacing along the $a$ axis.

In atmospheres containing water vapor, protons can be formed through the reaction

$$
\mathrm{H}_{2} \mathrm{O}+\mathrm{V}_{\mathrm{O}}^{\bullet \bullet}+\mathrm{O}_{\mathrm{O}}^{\mathrm{x}} \rightleftarrows 2 \mathrm{OH}_{\mathrm{O}}^{\cdot}
$$

$\mathrm{Liu}$ and Nowick found that $\mathrm{Nd}$-doped $\mathrm{BaCeO}_{3}$ was a very good proton conductor when exposed to a water vaporcontaining atmosphere ${ }^{8}$ but that $\mathrm{Eu}-, \mathrm{Yb}$-, and Gd-doped $\mathrm{BaCeO}_{3}$ were not. ${ }^{9}$ Proton conduction in moist atmospheres was also studied by Slade and Singh, who showed that $\mathrm{Gd}$-doped $\mathrm{BaCeO}_{3}$ had the highest conductivity

\footnotetext{
* Electrochemical Society Student Member.

** Electrochemical Society Active Member.
}

among compounds doped with $\mathrm{Y}, \mathrm{Gd}, \mathrm{Nd}$, and La. ${ }^{10}$ Stevenson et al. also found that $15 \% \mathrm{Gd}$-doped $\mathrm{BaCeO}_{3}$ had the highest total conductivity among $\mathrm{Yb}-, \mathrm{Nd}_{-}$, and Gd-doped samples in wet Ar. ${ }^{11}$

Formation of protons in alkaline earth cerates occurs readily in hydrogen-containing atmospheres according to

$$
\mathrm{H}_{2}+2 \mathrm{O}_{\mathrm{o}}^{\mathrm{X}} \rightleftarrows 2 \mathrm{OH}_{\mathrm{o}}^{*}+2 \mathrm{e}^{\prime}
$$

Nagamoto and Yamada have studied the effect of dopants for $\mathrm{A}$ and $\mathrm{B}$ sites on conductivity in hydrogen. ${ }^{12}$ Among $\mathrm{BaCeO}_{3}$ samples doped with $\mathrm{La}, \mathrm{Nd}, \mathrm{Yb}, \mathrm{Er}, \mathrm{Tb}$, and $\mathrm{Nb}$, $\mathrm{Nb}$-doped $\mathrm{BaCeO}_{3}$ showed the highest conductivity in hydrogen. High conductivity of $\mathrm{Nb}$-doped $\mathrm{BaCeO}_{3}$ in $\mathrm{H}_{2}$ was also observed by Rauch and Liu. ${ }^{13}$ However, electromotive force measurements indicated an absence of proton conduction in $\mathrm{Nb}$-doped $\mathrm{BaCeO}_{3} \cdot{ }^{12}$ At the same time, Iwahara et al. observed that $\mathrm{Y}-, \mathrm{Sm}-$, and $\mathrm{Nd}$-doped $\mathrm{BaCeO}_{3}$ had high conductivities in hydrogen, ${ }^{14,15}$ and that $20 \% \mathrm{Sm}-$ doped $\mathrm{BaCeO}_{3}$ exhibited very high total conductivity in hydrogen, $\left(\sim 4 \times 10^{-2} \Omega^{-1} \mathrm{~cm}^{-1}\right.$ at $\left.800^{\circ} \mathrm{C}\right)$. However, dense samples were difficult to prepare. According to a more recent report, ${ }^{2} \mathrm{BaCe}_{0.8} \mathrm{Y}_{0.2} \mathrm{O}_{3-\delta}$ may have the highest conductivity reported to date, $\sim 5.3 \times 10^{-2} \Omega^{-1} \mathrm{~cm}^{-1}$ at $800^{\circ} \mathrm{C}$ in hydrogen.

$\mathrm{SrCeO}_{3}$ doped with $\mathrm{Yb}^{16}$ and $\mathrm{Y}^{17}$ have also been studied as proton conductors. Compared to $\mathrm{BaCeO}_{3}$ based materials, $\mathrm{SrCeO}_{3}$ based materials have lower total conductivities but higher proton transference numbers.$^{18}$ Their higher proton transference numbers may make these materials desirable for hydrogen separation due to increased hydrogen selectivity. However, the electronic transference number of Y-doped $\mathrm{SrCeO}_{3}$ (and $\mathrm{BaCeO}_{3}$ ) was $<0.2$ at $800^{\circ} \mathrm{C}$, based on open-cell voltage measurements on hydrogen concentration cells. ${ }^{19,20}$ Also, the materials exhibited high interfacial polarization during hydrogen permeation tests. ${ }^{20}$ In order to improve catalytic properties and electronic conductivity, appropriate dopants or a second phase must be introduced. Typically, elements in group VIII, such as $\mathrm{Fe}, \mathrm{Co}$, and $\mathrm{Ni}$, are good catalysts, and Ni-oxide cermet has already been used as anode material in SOFCs because of its good catalytic properties and high electronic conductivity. ${ }^{21}$

In addition to stoichiometric alkaline earth cerates, $\mathrm{BaCeO}_{3}$ containing excess $\mathrm{BaO}^{22}$ and complex perovskites with the formula of $\mathrm{A}_{3} \mathrm{~B}_{1+x}^{\prime} \mathrm{Nb}_{2-x} \mathrm{O}_{9-8}(\mathrm{~A}=\mathrm{Ba}, \mathrm{Sr}, \mathrm{Ca}$, and $\left.\mathrm{B}^{\prime}=\mathrm{Sr}, \mathrm{Ca}, \mathrm{Mg}\right)^{23}$ have been studied. After water uptake measurements and conductivity analysis, Kreuer et al. ${ }^{22}$ concluded that excess $\mathrm{BaO}$ formed a grain boundary phase. Recently, Shima and Haile ${ }^{24}$ reported that excess $\mathrm{BaO}$ aids in densification and enhances the conductivity of $15 \% \mathrm{Gd}$-doped $\mathrm{BaCeO}_{3}$ in wet $\mathrm{Ar}$ at $500^{\circ} \mathrm{C}$, but samples with $4 \% \mathrm{BaO}$ excess eventually lost mechanical integrity due to reaction with atmospheric $\mathrm{CO}_{2}$ 
In this study, stoichiometric and nonstoichiometric $\mathrm{BaCeO}_{3}$ and $\mathrm{SrCeO}_{3}$ were doped with various materials ( $\mathrm{Gd}$, $\mathrm{Nd}, \mathrm{Y}$, and $\mathrm{Ni}$ ) at different dopant levels $(5,10$, and $20 \%)$, and the effects of these composition variations on sinterability, microstructure, and conductivity were characterized.

\section{Experimental}

Sample preparation.- $\mathrm{BaCeO}_{3}$ and $\mathrm{SrCeO}_{3}$ based materials were prepared by using solid-state reactions. ${ }^{19,20}$ All powders in this study had a perovskite structure except $\mathrm{SrCe}_{0.8}\left(\mathrm{Ni}_{0.1} \mathrm{Y}_{0.1}\right) \mathrm{O}_{3-\delta}$, in which $\mathrm{CeO}_{2}$ was detected by X-ray diffraction (Scintag, XDS 2000). Pellets of doped $\mathrm{BaCeO}_{3}$ were sintered in air at $1550^{\circ} \mathrm{C}$ for $10 \mathrm{~h} . \mathrm{SrCeO}_{3}$ based materials without $\mathrm{Ni}$ dopant were sintered in air at $1500^{\circ} \mathrm{C}$ for $10 \mathrm{~h}$, whereas, materials with $\mathrm{Ni}$ dopant were sintered in air at $1300^{\circ} \mathrm{C}$ for $5 \mathrm{~h}$. Both sides of each pellet were then polished with 600 grit $\mathrm{SiC}$ polishing paper. Platinum (Heraeus CL11-5100) or silver (Heraeus C1000) paste was painted on the polished surfaces and dried in air at $150^{\circ} \mathrm{C}$ for $5 \mathrm{~h}$ and subsequently fired in air for $12 \mathrm{~min}$ at $1200^{\circ} \mathrm{C}$ (for $\mathrm{Pt}$ paste) or at $850^{\circ} \mathrm{C}$ (for $\mathrm{Ag}$ paste) to form porous electrodes for electrochemical measurements.

Microstructure.-Microstructures of materials were studied by scanning electron microscopy (SEM; JEOL JSM-5400) on as-sintered surfaces, fracture surfaces, and etched surfaces. To prepare an etched surface, the pellet was first polished with 600 grit $\mathrm{SiC}$ polishing paper, then immersed in $1 \mathrm{~N} \mathrm{HNO}_{3}$ solution for $2 \mathrm{~min}$, and finally cleaned in isopropyl achohol.

Impedance spectroscopy.-An impedance analyzer (HP4192A LF) was used to acquire impedance spectra in the frequency range from $5 \mathrm{~Hz}$ to $13 \mathrm{MHz}$ at temperatures between 550 and $800^{\circ} \mathrm{C}$. Before the impedance measurements, each cell was first equilibrated at $800^{\circ} \mathrm{C}$ for $5 \mathrm{~h}$ and then cooled to $550^{\circ} \mathrm{C}$ in the desired atmosphere $\left(\mathrm{O}_{2}, \mathrm{H}_{2}\right.$, or wet $\mathrm{Ar}$ ). Water vapor was obtained by bubbling $\mathrm{Ar}$ through deionized water at room temperature $\left(\sim 22^{\circ} \mathrm{C}\right)$.

$\mathrm{H}^{+} / \mathrm{O}^{2-}$ transference number-The ratios of proton and oxygen ion transference numbers to the total ionic transference numbers were obtained by discharging a fuel cell

$$
\mathrm{O}_{2} \text {, Pt I doped } \mathrm{SrCeO}_{3} \text { I Pt, } 4 \% \mathrm{H}_{2}+\mathrm{Ar}
$$

with the external circuit shorted. The ratios $\left(t_{\mathrm{H}^{+}} / t_{\text {ion }}\right.$ and $\left.t_{\mathrm{O}^{2}-} / t_{\text {ion }}\right)$ were calculated from discharging currents and water vapor evolution rates of the cathode and anode compartments ${ }^{4,7,20}$ using

$$
\begin{aligned}
& \frac{t_{\mathrm{H}^{+}}}{t_{\mathrm{ion}}}=\frac{w_{\mathrm{c}}}{w_{\mathrm{t}}} \\
& \frac{t_{\mathrm{o}^{2-}}}{t_{\mathrm{ion}}}=\frac{w_{\mathrm{a}}}{w_{\mathrm{i}}}
\end{aligned}
$$

and

$$
t_{\text {ion }}=t_{\mathrm{H}^{*}}+t_{\mathrm{O}^{2-}}
$$

where $w_{\mathrm{c}}$ and $w_{\mathrm{a}}$ are the rates of water vapor evolution from the cathode side and anode side, respectively, and $w_{\mathrm{t}}$ is the total rate of water vapor evolution from both sides or calculated from the short-circuit currents (using Faraday's law). The rates of water vapor evolution due to electrochemical process were calculated from the flow rates of carrier gas and humidity measurements by a hygrometer (Fisher Scientific) in both sides of the cell under both open-circuit and short-circuit conditions. This procedure provides relative transference numbers only. To measure the absolute transference numbers, a separate experiment would be needed to determine the electronic contribution.

\section{Results and Discussion}

Material sintering.-Initially, green pellets were placed directly on an $\mathrm{Al}_{2} \mathrm{O}_{3}$ setter for sintering. After sintering, the surface areas in contact with alumina were yellowish, while the uncontacted surface areas were brown or dark green, depending on the initial material composition. The large difference in color suggested a reaction with the setter. As expected, the X-ray diffraction analysis of the contacted surface areas revealed the presence of $\mathrm{CeO}_{2}$ as the major phase and $\mathrm{BaCeO}_{3}$ as a minor phase (Fig. 1a). An Xray diffraction analysis of the uncontacted surface areas (the so-called free surface) showed the perovskite structure of $\mathrm{BaCeO}_{3}$, and possibly a trace amount of $\mathrm{CeO}_{2}$, due to $\mathrm{BaO}$ loss at high temperature (Fig. $1 \mathrm{~b}$ ). Cross-sectional views (Fig. 2a) showed clearly the formation of a reacted

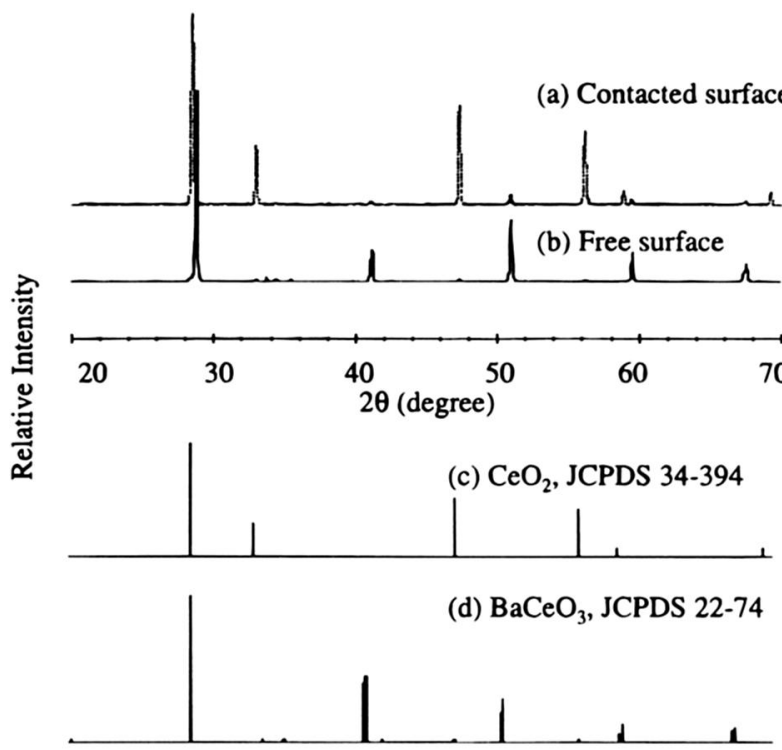

Fig. 1. X-ray diffraction patterns of $20 \% \mathrm{Gd}$-doped $\mathrm{BaCeO}_{3}$, showing a composition change when contacted by alumina sefter during sintering.

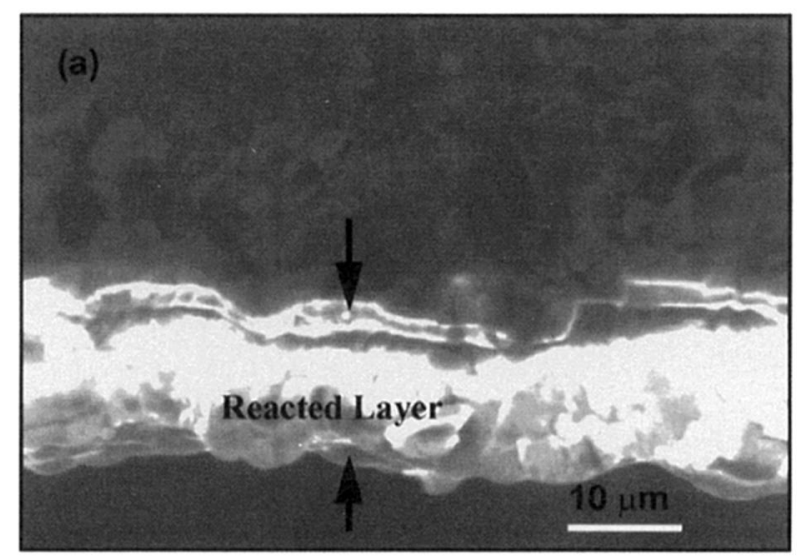

(b)

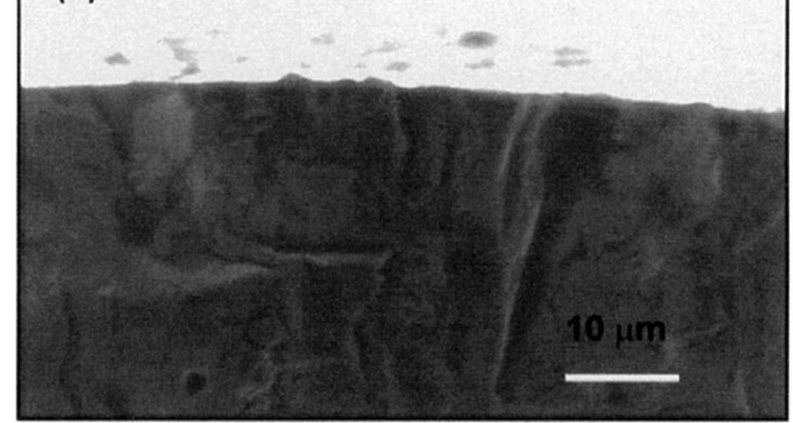

Fig. 2. SEM photomicrographs of (a) cross section of contacted surface and (b) cross section of free surface of $20 \% \mathrm{Gd}$-doped $\mathrm{BaCeO}_{3}$. 
Fig. 3. SEM photomicrographs of as-sintered surfaces of (a) $\mathrm{SrCeO}_{3}$, (b) $5 \% \mathrm{Y}-\mathrm{SrCeO}_{3}$ (c) $10 \% \quad \mathrm{Y}-\mathrm{SrCeO}_{3}$, and (d) $\mathrm{SrO} \cdot 0.90 \mathrm{CeO}_{2} \cdot 0.025 \mathrm{Y}_{2} \mathrm{O}_{3}$. All samples were sintered in air at $1500^{\circ} \mathrm{C}$.
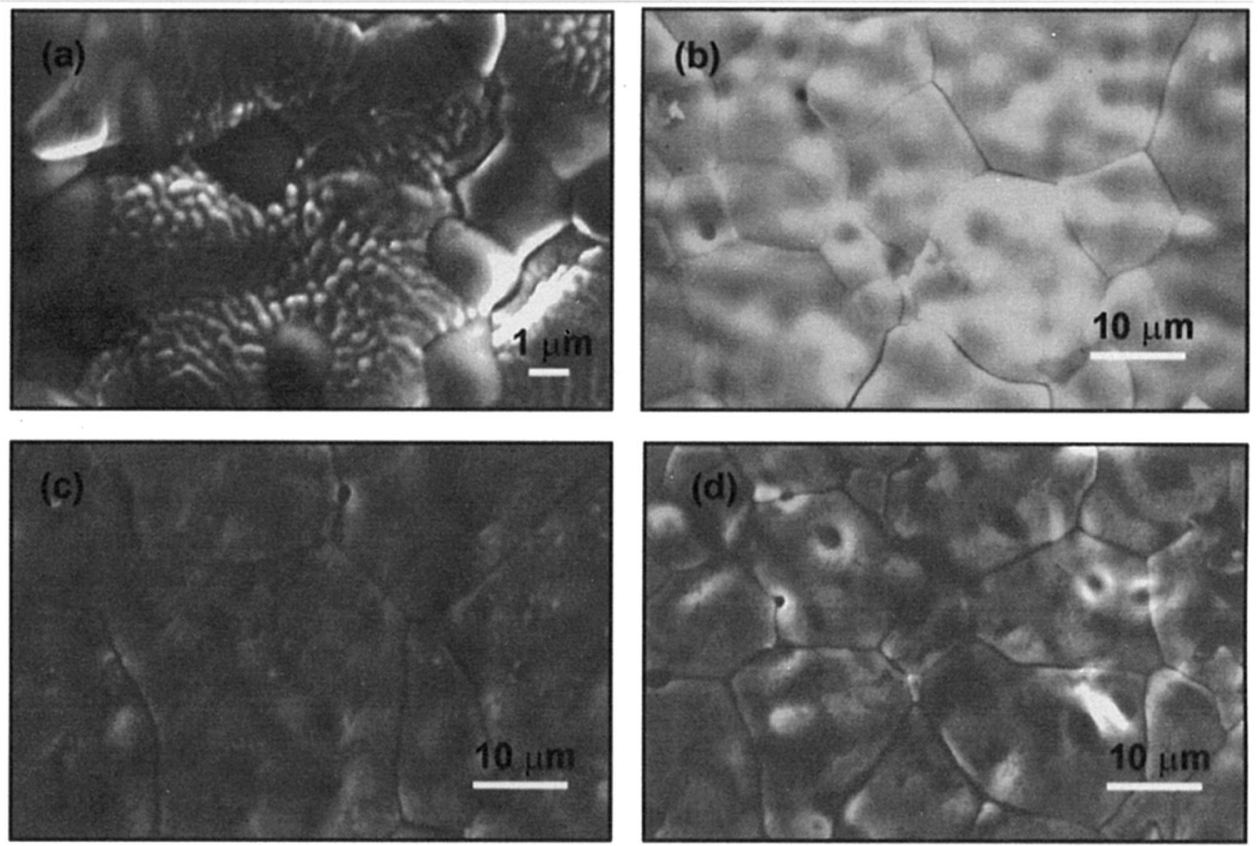

layer 10 to $15 \mu \mathrm{m}$ thick, whereas no such layer was evident in materials that did not contact $\mathrm{Al}_{2} \mathrm{O}_{3}$ (Fig. 2b). Energy dispersive X-ray (EDX) analysis showed that the molar ratio of $\mathrm{Ba}$ over $\mathrm{Ce}$ in the reacted layer was $\sim 1: 9$. Similar reactions were evident after sintering other doped $\mathrm{BaCeO}_{3}$ and $\mathrm{SrCeO}_{3}$ on $\mathrm{Al}_{2} \mathrm{O}_{3}$ setters, suggesting a reaction such as

$$
\mathrm{Ba}(\mathrm{Sr}) \mathrm{CeO}_{3}+\mathrm{Al}_{2} \mathrm{O}_{3} \rightleftarrows \mathrm{CeO}_{2}+\mathrm{Ba}(\mathrm{Sr}) \mathrm{Al}_{2} \mathrm{O}_{4}
$$

Such a reaction between $\mathrm{Ba}(\mathrm{Sr}) \mathrm{CeO}_{3}$ and $\mathrm{Al}_{2} \mathrm{O}_{3}$ must be considered in fabricating thin films of $\mathrm{Ba}(\mathrm{Sr}) \mathrm{CeO}_{3}$ on alumina substrates. ${ }^{25,26}$ To prevent the reaction in the present study, powders with the same composition as the green pellets were used as a buffer layer between the green pellets and the setter.

Microstructure.-Photomicrographs of as-sintered surfaces of $\mathrm{SrCeO}_{3}$ based materials (Fig. 3) show that both stoichiometric and nonstoichiometric (i.e., with excess $\mathrm{SrO}$ ) $\mathrm{SrCeO}_{3}$ can be densified at $1500^{\circ} \mathrm{C}$. Increasing the temper- ature to $1550^{\circ} \mathrm{C}$ caused extra grain growth. Undoped $\mathrm{SrCeO}_{3}$ showed a rough surface with honeycomblike structure (Fig. 3a). A similar structure was observed by Du and Nowick on a thermally etched $\mathrm{Ba}_{3} \mathrm{Ca}_{115} \mathrm{Nb}_{185} \mathrm{O}_{9-8}$ surface. ${ }^{27}$ Under identical sintering conditions (temperature and dwell time), grain growth increased as dopant level increased (Fig. 3a, b, and c).

Photomicrographs of $\mathrm{BaCeO}_{3}$ based materials sintered at $1550^{\circ} \mathrm{C}$ are shown in Fig. 4. In this study, stoichiometric $5 \%$ Y-doped $\mathrm{BaCeO}_{3}$ did not densify well ( $\sim 89 \%$ dense; Fig. 4a), whereas a sample with $5 \%$ excess $\mathrm{BaO}$ $\left(\mathrm{BaO} \cdot 0.90 \mathrm{CeO}_{2} \cdot 0.025 \mathrm{Y}_{2} \mathrm{O}_{3}\right)$ had a very dense fracture surface $(\sim 94 \%$; Fig. $4 \mathrm{~b})$. This suggests that the proper amount of excess $\mathrm{BaO}$ promotes sintering for this dopant level $(5 \% \mathrm{Y})$. At higher dopant concentration $(10 \% \mathrm{Y})$, however, the stoichiometric material was very dense ( $\sim 98 \%$; Fig. $4 \mathrm{c})$, whereas, the sample with $5 \%$ excess $\mathrm{BaO}$ $\left(\mathrm{BaO} \cdot 0.85 \mathrm{CeO}_{2} \cdot 0.05 \mathrm{Y}_{2} \mathrm{O}_{3}\right)$ was not very dense $(\sim 91 \%$ dense) and had finer grains (Fig. $4 \mathrm{~d}$ ). The observation of

Fig. 4. SEM photomicrographs of (a) fracture surface of $5 \%$ $\mathrm{Y}-\mathrm{BaCeO}_{3}$, (b) fracture surface of $\mathrm{BaO} \cdot 0.90 \mathrm{CeO}_{2} \cdot 0.025 \mathrm{Y}_{2} \mathrm{O}_{3}$ (c) as-sintered surface of $10 \% \mathrm{Y}-\mathrm{BaCeO}_{3}$, and (d) assintered surface of $\mathrm{BaO} \cdot 0.85 \mathrm{CeO}_{2} \cdot 0.05 \mathrm{Y}_{2} \mathrm{O}_{3}$. All samples were sintered in air at $1550^{\circ} \mathrm{C}$.
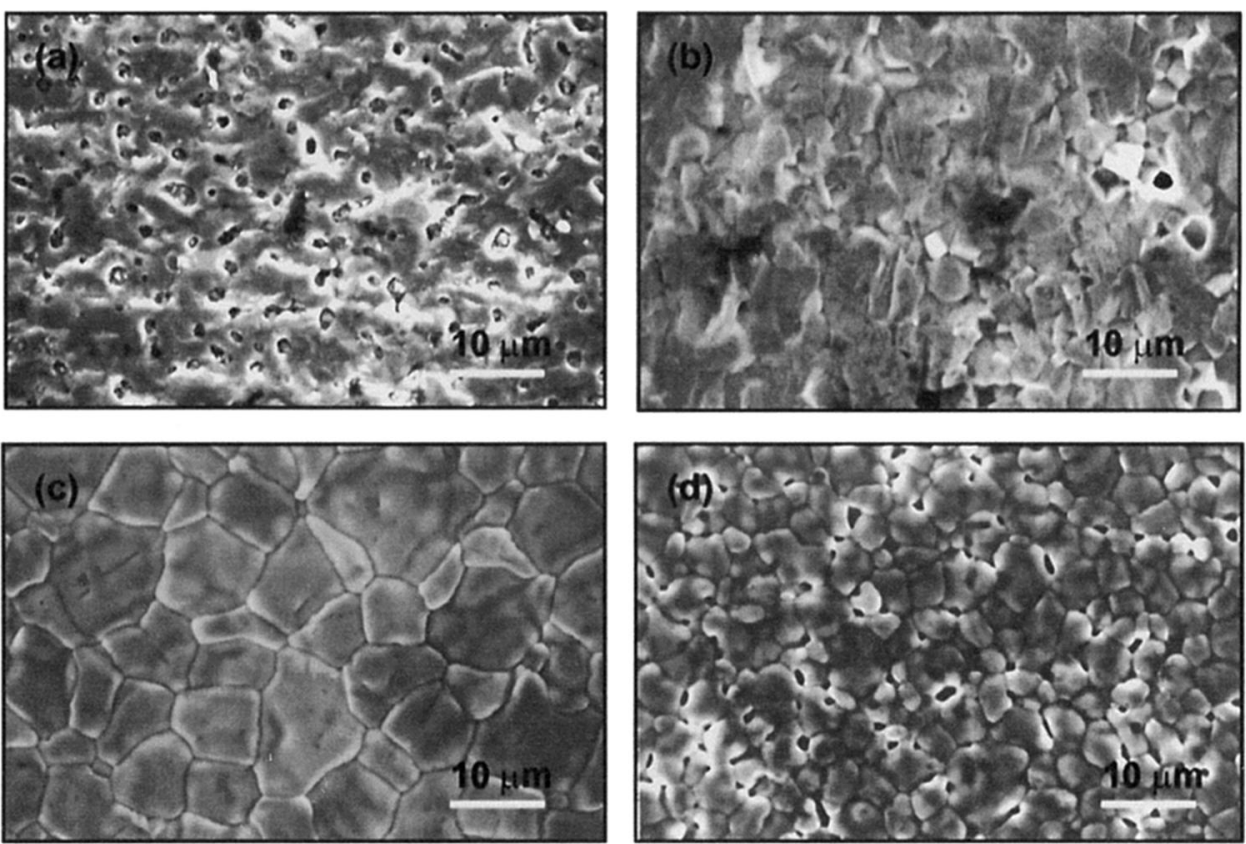
Kulscar ${ }^{28}$ that $2 \mathrm{~mol} \%$ excess $\mathrm{BaO}$ in $\mathrm{BaTiO}_{3}$ acted as a grain size refiner suggests that the excess $\mathrm{BaO}$ may inhibit grain growth in the $10 \%$ Y-doped sample.

Excess $\mathrm{BaO}$ may incorporate into the perovskite up to the solubility limit according to defect reactions ${ }^{24,29}$

$$
\mathrm{BaO} \rightleftarrows \mathrm{Ba}_{\mathrm{Ba}}^{\mathrm{x}}+\mathrm{O}_{\mathrm{O}}^{\mathrm{x}}+V_{\mathrm{Ce}}^{\prime \prime \prime \prime}+2 V_{\mathrm{o}}^{\cdot \cdot}
$$

and

$$
2 \mathrm{BaO} \rightleftarrows \mathrm{Ba}_{\mathrm{Ba}}^{\mathrm{x}}+\mathrm{Ba}_{\mathrm{Ce}}^{\prime \prime}+2 \mathrm{O}_{\mathrm{O}}^{\mathrm{x}}+V_{\mathrm{o}}^{*}
$$

At low dopant concentrations, the forward reactions may be favored because the concentration of oxygen vacancies introduced by the dopant is relatively small. As a result, excess $\mathrm{BaO}$ can be easily incorporated into the structure to create additional oxygen vacancies, which improve vacancy diffusion and thereby promote sintering. Higher dopant concentrations, however, may saturate the material with oxygen vacancies, in which case the forward reactions in $5 \mathrm{a}$ and $5 \mathrm{~b}$ became less favorable. As a result, $\mathrm{Ba}$-rich phases may segregate at grain boundaries, thus impeding sintering.

Effects of excess $\mathrm{BaO}$ on microstructure were also studied by examining $5 \%$ Y-doped $\mathrm{BaCeO}_{3}$ with and without excess $\mathrm{BaO}$ after acid etching. After acid etching for 2 min in $\mathrm{HNO}_{3}$, the sample with $5 \%$ excess $\mathrm{BaO}$ $\left(\mathrm{BaO} \cdot 0.90 \mathrm{CeO}_{2} \cdot 0.025 \mathrm{Y}_{2} \mathrm{O}_{3}\right)$ showed clearly distinguished grains (Fig. 5a), but the stoichiometric doped $\mathrm{BaCeO}_{3}$ $\left(\mathrm{BaCe}_{0.95} \mathrm{Y}_{0.05} \mathrm{O}_{3-\delta}\right)$ was randomly corroded (Fig. 5b) with finer grains. Although excess $\mathrm{BaO}$ acted as a grain size refiner in $\mathrm{BaO} \cdot 0.85 \mathrm{CeO}_{2} \cdot 0.05 \mathrm{Y}_{2} \mathrm{O}_{3}$ (Fig. 4 d), the observation of coarser grains in $\mathrm{BaO} \cdot 0.90 \mathrm{CeO}_{2} \cdot 0.025 \mathrm{Y}_{2} \mathrm{O}_{3}$ rather than in $\mathrm{BaCe}_{0.95} \mathrm{Y}_{0.05} \mathrm{O}_{3-\delta}$ is exactly opposite. It is possible that most of excess $\mathrm{BaO}$ in the sample with low dopant concentration $\left(\mathrm{BaO} \cdot 0.90 \mathrm{CeO}_{2} \cdot 0.025 \mathrm{Y}_{2} \mathrm{O}_{3}\right)$ had already become incorporated into the matrix according to Eq. 5. This incorporation could create more vacancies and thus promote grain growth and densification. ${ }^{30}$ In the sample with the high dopant concentration $\left(\mathrm{BaO} \cdot 0.85 \mathrm{CeO}_{2} \cdot 0.05 \mathrm{Y}_{2} \mathrm{O}_{3}\right)$, however, most of the excess $\mathrm{BaO}$ may exist as grain bound-
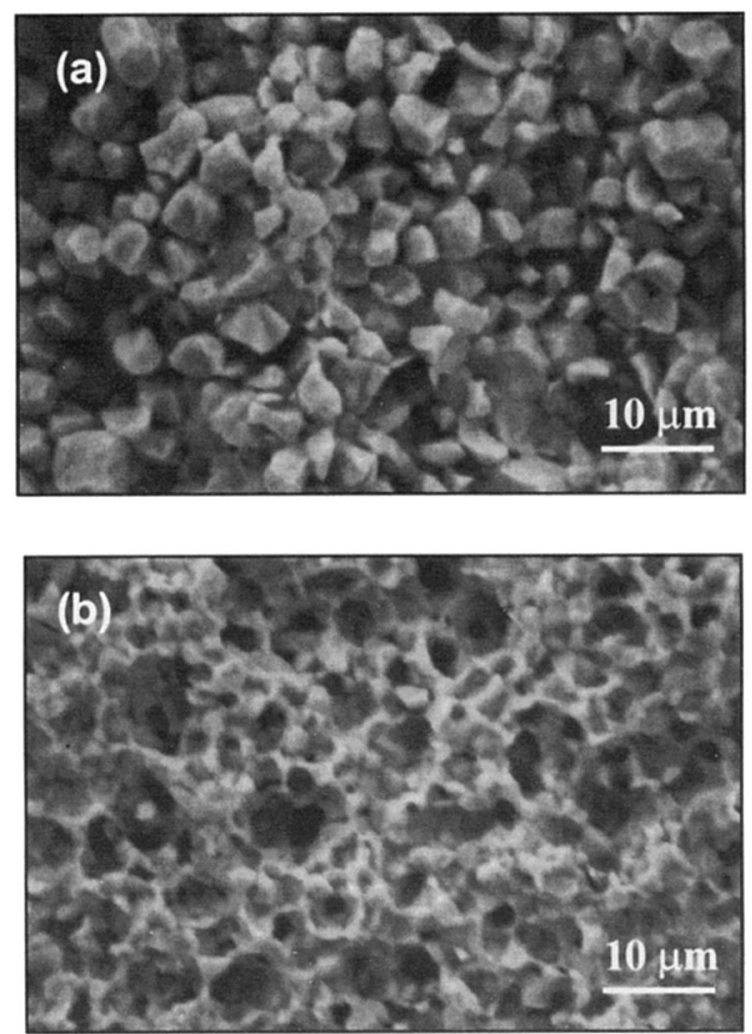

Fig. 5. SEM photomicrographs of (a) acid-etched surface of $\mathrm{BaO} \cdot 0.90 \mathrm{CeO}_{2} \cdot 0.025 \mathrm{Y}_{2} \mathrm{O}_{3}$ and (b) acid-etched surface of $5 \% \mathrm{Y}$ $\mathrm{BaCeO}_{3}$ ary phases due to oxygen vacancy saturation in the matrix. The existence of excess $\mathrm{BaO}$ at grain boundaries in $\mathrm{BaO} \cdot 0.85 \mathrm{CeO}_{2} \cdot 0.05 \mathrm{Y}_{2} \mathrm{O}_{3}$, however, could act as a grain-size refiner and impede sintering. ${ }^{28}$

As for stability, samples with compositions of $\mathrm{SrO} \cdot 0.90 \mathrm{CeO}_{2} \cdot 0.025 \mathrm{Y}_{2} \mathrm{O}_{3}, \quad \mathrm{SrO} \cdot 0.85 \mathrm{CeO}_{2} \cdot 0.05 \mathrm{Y}_{2} \mathrm{O}_{3}$, and $1.05 \mathrm{SrO} \cdot \mathrm{CeO}_{2}$ appeared to be acceptable immediately after sintering, but crumbled into pieces after exposure to air for several days. After exposure to air for many weeks, as-sintered $\mathrm{BaO} \cdot 0.90 \mathrm{CeO}_{2} \cdot 0.025 \mathrm{Y}_{2} \mathrm{O}_{3}$ and $\mathrm{Ba} \cdot 0.85 \mathrm{CeO}_{2} \cdot 0.05 \mathrm{Y}_{2} \mathrm{O}_{3}$ pellets, however, retained good mechanical integrity. However, if the as-sintered pellets were broken into two pieces and then exposed to air, $\mathrm{BaO} \cdot 0.90 \mathrm{CeO}_{2} \cdot 0.025 \mathrm{Y}_{2} \mathrm{O}_{3}$ maintained good integrity while $\mathrm{Ba} \cdot 0.85 \mathrm{CeO}_{2} \cdot 0.05 \mathrm{Y}_{2} \mathrm{O}_{3}$ crumbled. The lower stability in air of $\mathrm{BaO} \cdot 0.85 \mathrm{CeO}_{2} \cdot 0.05 \mathrm{Y}_{2} \mathrm{O}_{3}$ than that of $\mathrm{BaO} \cdot 0.90 \mathrm{CeO}_{2} \cdot 0.025 \mathrm{Y}_{2} \mathrm{O}_{3}$ suggested that the former may have more Ba-rich phases at grain boundaries than the latter. Scanning electron microscopy (SEM) examination on fracture surfaces of $\mathrm{BaO} \cdot 0.90 \mathrm{CeO}_{2} \cdot 0.025 \mathrm{Y}_{2} \mathrm{O}_{3}$ showed that the entire fracture surface is dense, as shown in Fig. $4 \mathrm{~b}$, and that there was no observable change after the fracture surface was exposed to air for four weeks. However, after exposure of sintered $\mathrm{BaO} \cdot 0.85 \mathrm{CeO}_{2} \cdot 0.05 \mathrm{Y}_{2} \mathrm{O}_{3}$ to air for two weeks, examination of the center portion of the fracture surface revealed a $\mathrm{Ba}$-rich phase in the grain boundaries (Fig. 6). EDX analysis showed that the molar ratio of $\mathrm{Ba}$ over $\mathrm{Ce}$ is $\sim 91: 9$ in the $\mathrm{Ba}$-rich phase, while neighboring grains had a molar ratio of $\mathrm{Ba}: \mathrm{Ce}: \mathrm{Y} \sim 49: 44: 7$, close to the mixture ratio of $\mathrm{Ba}: \mathrm{Ce}: \mathrm{Y}=100: 85: 10$ when the material was prepared. The observation of a Ba-rich phase in $\mathrm{BaO} \cdot 0.85 \mathrm{CeO}_{2} \cdot 0.05 \mathrm{Y}_{2} \mathrm{O}_{3}$ confirmed our assumption that the excess $\mathrm{BaO}$ likely exists in the grain boundary area of the sample with high dopant concentration due to the possible saturation of oxygen vacancies. Such a Ba-rich phase was not observed in the surface layer of the sintered pellet because $\mathrm{BaO}$ was probably vaporized at high temperature during sintering. As such, the stable surface layer prevented the Ba-rich phase in the center of the sintered body from further reacting with atmospheric $\mathrm{CO}_{2}$, thereby maintaining the good integrity of the as-sintered pellets. However, after the pellet was broken, the Ba-rich phase inside the sintered body was readily accessed by atmospheric $\mathrm{CO}_{2}$, forming $\mathrm{BaCO}_{3}$ and consequently causing the crumbling of the pellet.

Conductivity of $\mathrm{BaCeO}_{3}$ based materials.-Temperature dependence of stoichiometric doped $\mathrm{BaCeO}_{3}$ - Shown in Fig. $7 \mathrm{a}$ are the total conductivities of doped $\mathrm{BaCeO}_{3}$ in 1 atm oxygen as determined by impedance spectroscopy. The total conductivity of Y-doped $\mathrm{BaCeO}_{3}$ increased with temperature. The conductivity of $\mathrm{BaCe}_{0.8} \mathrm{Gd}_{0.2} \mathrm{O}_{3-6}{ }_{6}$ was slightly higher than that of $\mathrm{BaCe}_{0.9} \mathrm{Y}_{0.1} \mathrm{O}_{3-\delta}$ and $\mathrm{BaCe}_{0.8} \mathrm{Y}_{0.2} \mathrm{O}_{3-\delta}$ in this work at temperatures $<700^{\circ} \mathrm{C}$, but was almost the same at $>700^{\circ} \mathrm{C}$.

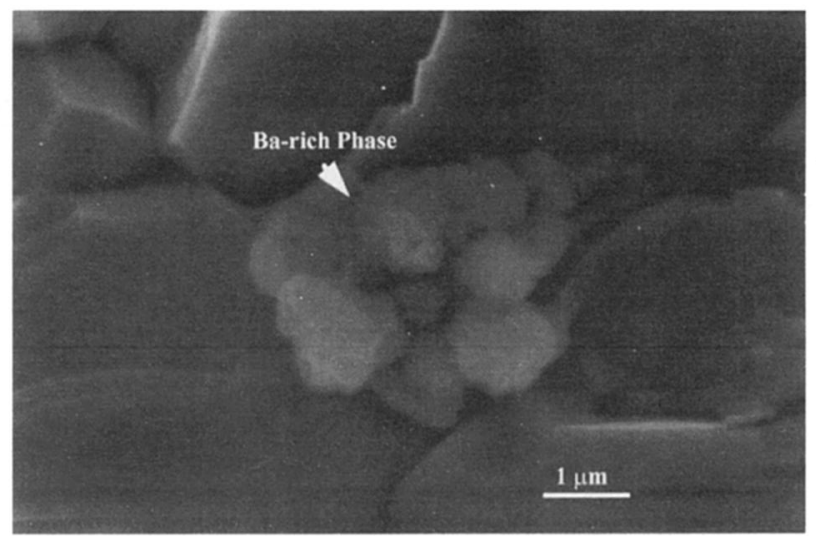

Fig. 6. SEM photomicrograph of fracture surface of $\mathrm{BaO} \cdot 0.85 \mathrm{CeO}_{2} \cdot 0.05 \mathrm{Y}_{2} \mathrm{O}_{3}$ after exposure to air for 2 weeks. 

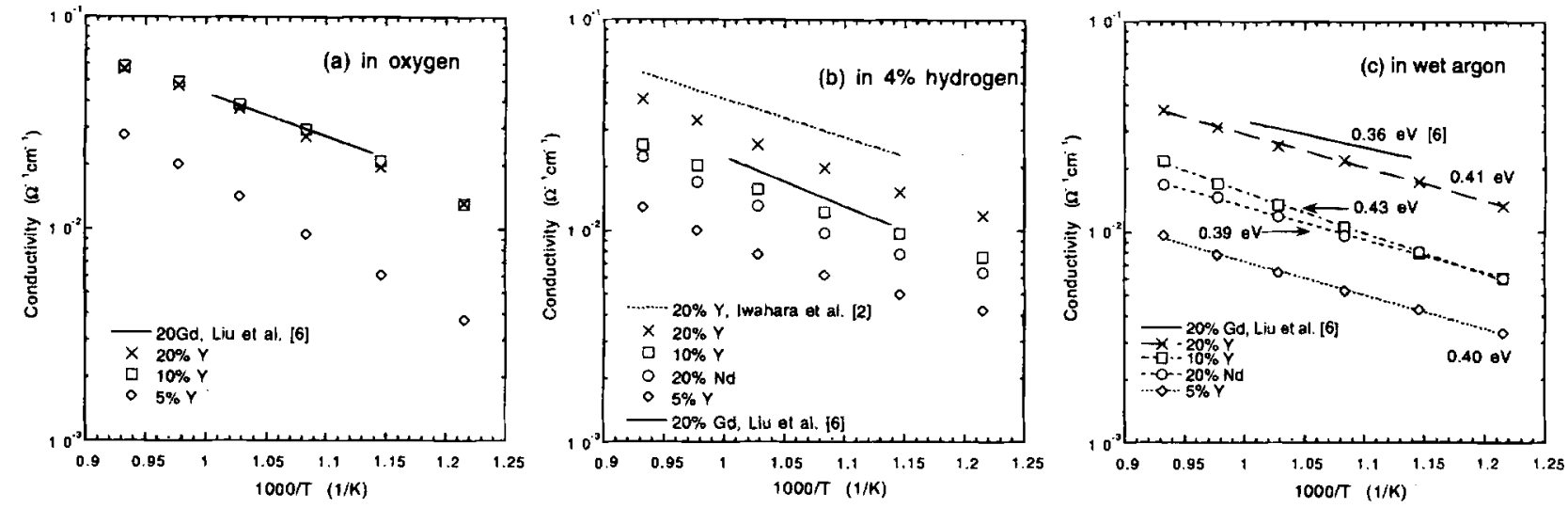

Fig. 7. Temperature dependence of conductivity of $\mathrm{BaCeO}_{3}$ based materials in (a) $\mathrm{O}_{2},(\mathrm{~b}) 4 \% \mathrm{H}$, and (c) wet $\mathrm{Ar}$.

Shown in Fig. 7b is the temperature dependence of conductivity in $4 \% \mathrm{H}$. The conductivities of samples with 5 , 10 , and $20 \% \mathrm{Y}$ increased with dopant concentration. For $\mathrm{BaCeO}_{3}$ doped with $20 \% \mathrm{Y}, \mathrm{Nd}$, and $\mathrm{Gd}$, the conductivity increased in the order of $\mathrm{Nd}, \mathrm{Gd}$, and $\mathrm{Y}$ at a given temperature. Contrary to expectation, the conductivity of $20 \%$ $\mathrm{Nd}$-doped $\mathrm{BaCeO}_{3}$ was not very high. Moreover, $20 \% \mathrm{Y}-$ doped $\mathrm{BaCeO}_{3}$ had the highest conductivity in this work, $\sim 1.54 \times 10^{-2} \Omega^{-1} \mathrm{~cm}^{-1}$ at $600^{\circ} \mathrm{C}$ and $\sim 4.16 \times 10^{-2} \Omega^{-1} \mathrm{~cm}^{-1}$ at $800^{\circ} \mathrm{C}$. Compared to the results of Iwahara et al..$^{2}$ for $20 \% \mathrm{Y}$-doped $\mathrm{BaCeO}_{3}$ in $\mathrm{H}_{2}$, the conductivities in this work are lower, partially because measurements in the present study were made in $4 \% \mathrm{H}_{2}$ instead of $100 \%$ pure hydrogen.

Shown in Fig. $7 \mathrm{c}$ is the temperature dependence of conductivity in wet Ar. The conductivity of Y-doped $\mathrm{BaCeO}_{3}$ increased with dopant concentration. Among the samples with $20 \%$ dopants, conductivity increased in the order of $\mathrm{Nd}-, \mathrm{Y}_{-}$, and $\mathrm{Gd}$-doped $\mathrm{BaCeO}_{3}$ in the temperature range of 550 to $800^{\circ} \mathrm{C}$. The $20 \% \mathrm{Gd}$-doped $\mathrm{BaCeO}_{3}$ had the highest conductivity with the lowest activation energy $(\sim 0.31 \mathrm{eV})$ in wet $\mathrm{Ar},{ }^{6}$ whereas the activation energies for other materials were very close to one another, $\sim 0.4 \mathrm{eV}$.

Composition dependence of stoichiometric doped $\mathrm{BaCeO}_{3}$ - - For Y-doped $\mathrm{BaCeO}_{3}$, at a given temperature, conductivity measured in wet $\mathrm{Ar}$ (Fig. 7c) and $4 \% \mathrm{H}_{2}$ (Fig. 8a) which is dominated by ionic conduction, increased monotonically with dopant concentration from 5 to $20 \%$. In $\mathrm{O}_{2}$, however, there is a significant contribution from electron hole conduction; conductivity increased with dopant concentration from 5 to $10 \%$, and then decreased slightly with dopant concentration up to $20 \%$. The smooth curve in Fig. $8 \mathrm{~b}$ implies a possible maximum between 10 and $20 \%$ The increase in conductivity with dopant concentration could be related to an increase in charge carrier concentration through the reaction

$$
\mathrm{Y}_{2} \mathrm{O}_{3} \stackrel{\mathrm{CeO}_{2}}{\longrightarrow} 2 \mathrm{Y}_{\mathrm{Ce}}^{\prime}+3 \mathrm{O}_{\mathrm{O}}^{\mathrm{x}}+\mathrm{V}_{\mathrm{o}}^{*}
$$

However, sintered density and defect structure may also affect total conductivities.

Effects of $A: B$ site nonstoichiometry.-As shown in Fig. 9, samples with $\mathrm{BaO}$ excess had higher conductivity than the stoichiometric doped samples with $5 \% \mathrm{Y}$ as the dopant. However, at a higher dopant concentration (10\% $\mathrm{Y}$ ), excess $\mathrm{BaO}$ reduced the total conductivity, except at a lower temperature $\left(<600^{\circ} \mathrm{C}\right)$, in $\mathrm{H}_{2}$. This variation of conductivity with $\mathrm{BaO}$ excess could be correlated to the density change with $\mathrm{BaO}$ excess. At a $5 \%$ dopant level, $\mathrm{BaO} \cdot 0.90 \mathrm{CeO}_{2} \cdot 0.025 \mathrm{Y}_{2} \mathrm{O}_{3}$ had a greater density $(\sim 94 \%$ dense) than $\mathrm{BaCe}_{095} \mathrm{Y}_{0.05} \mathrm{O}_{3-\delta}(\sim 89 \%$ dense), whereas, at the $10 \%$ level, $\mathrm{BaO} \cdot 0.85 \mathrm{CeO}_{2} \cdot 0.05 \mathrm{Y}_{2} \mathrm{O}_{3}$ had a lesser density $(\sim 91 \%)$ than $\mathrm{BaCl}_{0.9} \mathrm{Y}_{01} \mathrm{O}_{3-5}(\sim 98 \%$; Fig. 4). However, Shima et al. found that $4 \%$ excess $\mathrm{BaO}$ reduced the conductivity of $15 \% \mathrm{Gd}$-doped $\mathrm{BaCeO}_{3}$ in wet $\mathrm{Ar}$ at lower temperatures $\left(250\right.$ to $400^{\circ} \mathrm{C}$ ) and enhanced it at higher temperatures $\left(500^{\circ} \mathrm{C}\right)$, even though the sample with excess $\mathrm{BaO}$ had increased density. They attributed the reduced conductivity at low temperature to defect association. ${ }^{24}$ This variation of conductivity with excess $\mathrm{BaO}$ may also
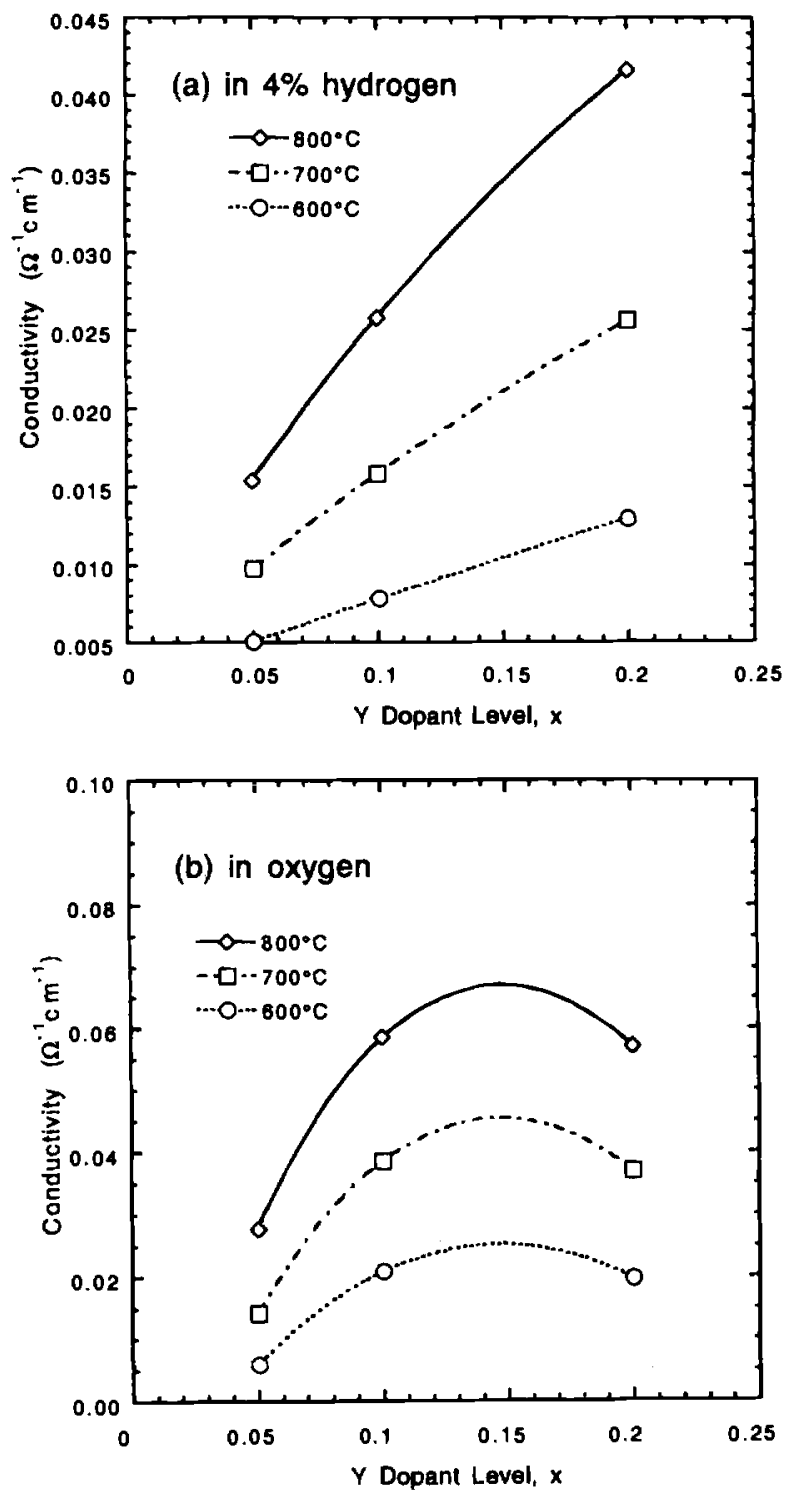

Fig. 8. Effects of dopant concentration on conductivity of $\mathrm{Y}$ doped $\mathrm{BaCeO}_{3}$ in (a) $4 \% \mathrm{H}_{2}$ and (b) $\mathrm{O}_{2}$. 

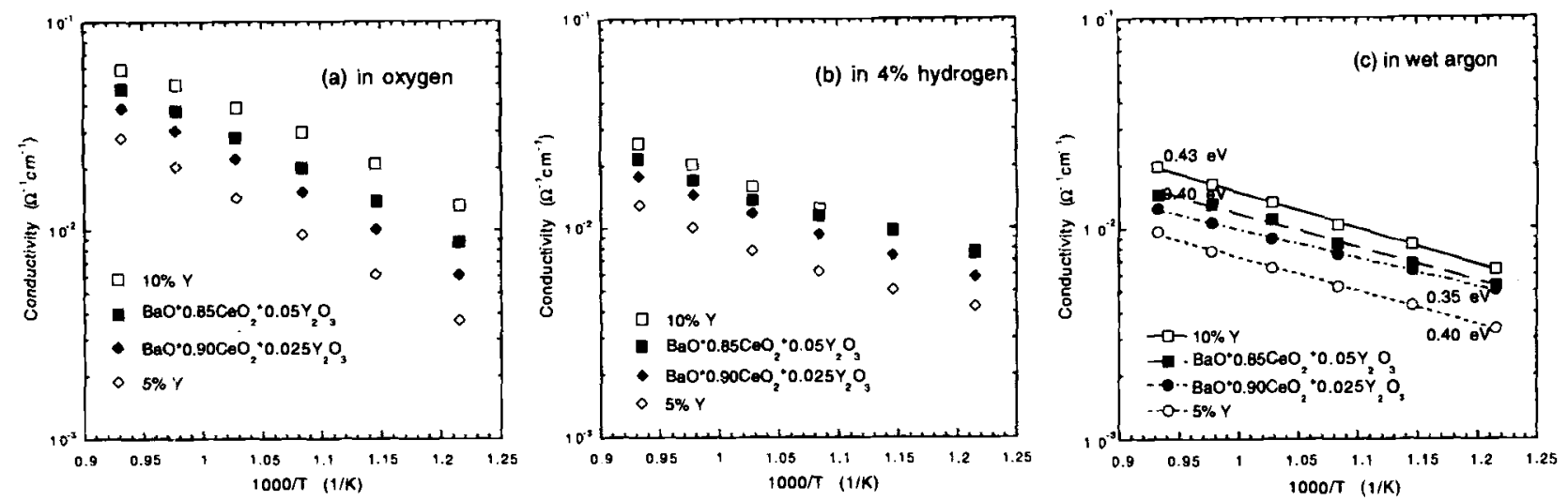

Fig. 9. Effects of nonstoichiometry on conductivity of $\mathrm{BaCeO}_{3}$ based materials in (a) $\mathrm{O}_{2}$, (b) $4 \% \mathrm{H}_{2}$, and (c) wet Ar.

be related to defect structure. At a low dopant concentration $(5 \% \mathrm{Y})$, incorporation of excess $\mathrm{BaO}$ into the perovskite matrix induces high vacancy concentration and increases conductivity, whereas at a high dopant concentration $(10 \% \mathrm{Y})$, excess $\mathrm{BaO}$ tends to reside in grain boundary phases that may inhibit conduction in the temperature range studied.

Conductivity of doped $\mathrm{SrCeO}_{3}-$ Shown in Fig. 10 are the total conductivities of doped $\mathrm{SrCeO}_{3}$ in oxygen and hydrogen. The conductivities for $\mathrm{BaCe}_{09} \mathrm{Y}_{01} \mathrm{O}_{3-8}$ under comparable conditions are reproduced from Fig. 7 for reference. Obviously, doped $\mathrm{SrCeO}_{3}$ had lower conductivities in $\mathrm{O}_{2}$ and $\mathrm{H}_{2}$ than those of $\mathrm{BaCeO}_{3}$ based materials. As with $\mathrm{BaCeO}_{3}$, conductivity increased as dopant concentration increased from 5 to $10 \%$ in both $\mathrm{O}_{2}$ and $\mathrm{H}_{2}$. The activation energy for conduction in $\mathrm{H}_{2}$ was lower than that in $\mathrm{O}_{2}$ Conductivity of $\mathrm{SrCe}_{0.8}\left(\mathrm{Ni}_{0.1} \mathrm{Y}_{0.1}\right) \mathrm{O}_{3-8}$ was surprisingly low $\left(\sim 10^{-5} \Omega^{-1} \mathrm{~cm}^{-1}\right.$ at $\left.650^{\circ} \mathrm{C}\right)$. The Ni was probably not a good dopant in terms of conductivity, ${ }^{31,32}$ although Ni-oxide cermets were reported to have good catalytic properties in SOFC applications. ${ }^{21}$

$\mathrm{H}^{+} / \mathrm{O}^{2-}$ conduction.-Figure 11 shows the relative ionic transference numbers of $\mathrm{SrCe}_{0.95} \mathrm{Y}_{0.05} \mathrm{O}_{3-5}$ in this work, as well as those of the $10 \% \mathrm{Y}$ - and $10 \% \mathrm{Gd}$-doped $\mathrm{BaCeO}_{3}$ that were reported by Iwahara et al. ${ }^{7}$ Compared to the results of $\mathrm{BaCeO}_{3}$ based materials, $\mathrm{SrCeO}_{3}$ based materials have higher proton transference numbers and lower oxy-

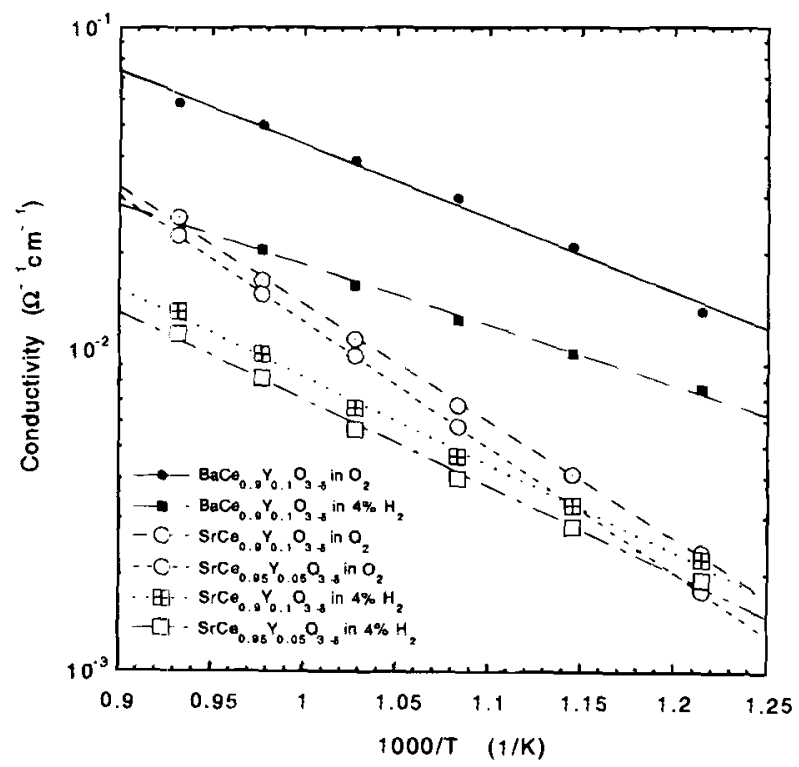

Fig. 10. Conductivities of doped $\mathrm{SrCeO}_{3}$ and $10 \%$ Y-doped $\mathrm{BaCeO}_{3}$ in $\mathrm{O}_{2}$ and $4 \% \mathrm{H}_{2}$. gen ion transference numbers. In $\mathrm{SrCe}_{0.95} \mathrm{Y}_{0.05} \mathrm{O}_{3-\delta}$, more than $85 \%$ of the ionic conductivity was carried by protons in the testing temperature range $\left(600-800^{\circ} \mathrm{C}\right)$ and oxygen ions contributed to only $\sim 15 \%$ of the ionic conductivity. Ionic conduction was completely protonic below $600^{\circ} \mathrm{C}$.

\section{Conclusions}

Dopant species and concentration strongly affected the microstructures and electrical properties of $\mathrm{BaCeO}_{3}$ and $\mathrm{SrCeO}_{3}$. Grain growth and densification of sintered samples were influenced by dopant level and nonstoichiometry on $\mathrm{A}$ and $\mathrm{B}$ sites. The conductivity of $\mathrm{BaCe}_{1-x} \mathrm{Y}_{x} \mathrm{O}_{3-\delta}(x=$ $0.05,0.1$, and 0.2 ) increased in hydrogen and wet $\mathrm{Ar}$ with $\mathrm{Y}$ content. Of the doped $\mathrm{BaCeO}_{3}, \mathrm{BaCe}_{0.8} \mathrm{Y}_{0.2} \mathrm{O}_{3-5}$ showed the highest conductivity in hydrogen $\left(\sim 1.54 \times 10^{-2} \Omega^{-1} \mathrm{~cm}^{-1}\right.$ at $600^{\circ} \mathrm{C}$ and $\sim 4.16 \times 10^{-2} \Omega^{-1} \mathrm{~cm}^{-1}$ at $800^{\circ} \mathrm{C}$ ). Although $\mathrm{SrCeO}_{3}$ based materials had lower conductivities than those of $\mathrm{BaCeO}_{3}$ based materials, they exhibited higher proton and lower oxygen ion transference numbers than $\mathrm{BaCeO}_{3}$, which may be useful for improving their selectivity for hydrogen separation.

\section{Acknowledgments}

This work was supported, and this manuscript created, under Contract W-31-109-Eng-38, of the U.S. Department of Energy, Federal Energy Technology Center.

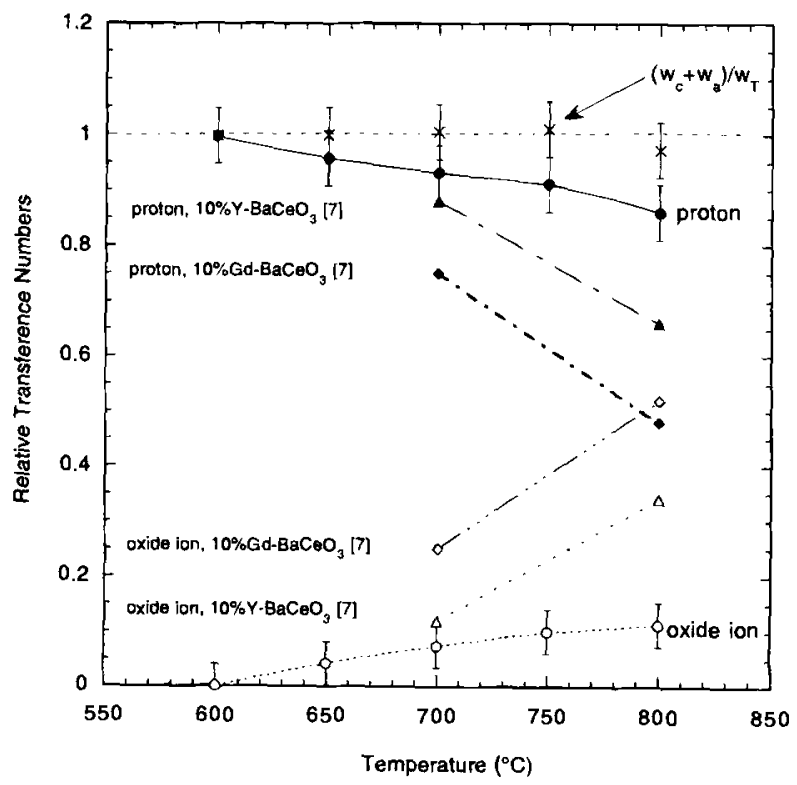

Fig. 11. Relative ionic transference numbers under fuel cell condition of $5 \% \mathrm{Y}_{-} \mathrm{SrCeO}_{3}$ in this work, and in $10 \%$ Y-doped $\mathrm{BaCeO}_{3}$ and $10 \% \mathrm{Gd}_{\text {-doped }} \mathrm{BaCeO}_{3}$ by Iwahara et $\mathrm{al}^{7}$ ? 
Manuscript submitted November 5, 1997; revised manuscript received January 27, 1998.

Argonne National Laboratory assisted in meeting the publication costs of this article.

\section{REFERENCES}

1. K. Kreuer, Chem. Mater, 8, 610 (1996).

2. H. Iwahara, Solid State Ionics, 77, 289 (1995)

3. J. A. Kilner and R. J. Brook, Solid State Ionics, 6, 237 (1982).

4. N. Bonanos, B. Ellis, K. S. Knight, and M. N. Mahmood, Solid State Ionics, 35, 179 (1989).

5. N. Taniguchi, K. Hatoh, J. Niikura, and T. Gamo, Solid State Ionics, 53-56, 998 (1992).

6. M. Liu, H. Hu, and W. Rauch, in Proceedings of the 1st International Symposium on Ceramic Membranes, H. U. Anderson, A. C. Khandkar, and M. Liu, Editors, PV 95-24, p. 191, The Electrochemical Society, Pennington, NJ (1996).

7. H. Iwahara, T. Yajima, and H. Ushida, Solid State Ionics, 70/71, 267 (1994).

8. J. F. Liu and A. S. Nowick, Solid State Ionics, 50, 131 (1992).

9. J. F. Liu and A. S. Nowick, Mater. Res. Soc. Symp. Proc.: Solid State Ionics II, 210, 675 (1991).

10. R. C. T. Slade and N. Singh, Solid State Ionics, 46, 111 (1991).

11. D. A. Stevenson, N. Jiang, R. M. Buchanan, and F. E. G. Henn, Solid State Ionics, 62, 279 (1993).

12. H. Nagamoto and H. Yamada, in Proceedings of the 2nd International Symposium on Ionic and Mixed Conducting Ceramics, T. A. Ramanarayanan, W. L. Worrell, and H. L. Tuller, Editors, PV 94-12, p. 39, The Electrochemical Society Proceedings Series, Pennington NJ (1994).

13. W. Rauch and M. Liu, in Proceedings of the 1st International Symposium on Ceramic Membranes, H. U. Anderson, A. C. Khandkar, and M. Liu, Editors,
PV 95-24, p. 146, The Electrochemical Society Proceedings Series, Pennington, NJ (1996).

14. H. Iwahara, H. Uchida, K. Ono, and K. Ogaki, J. Electrochem., Soc., 135, 529 (1988)

15. H. Iwahara, T. Yajima, T. Hibino, and H. Ushida, $J$ Electrochem., Soc., 140, 1687 (1993).

16. H. Iwahara, T. Hibino, and T. Sunano, J. Appl. Electrochem., 26, 829 (1996).

17. U. Reichel, R. R. Arons, and W. Schilling, Solid State Ionics, 86-88, 639 (1996).

18. K. S. Knight and N. Bonanos, Mater. Res. Bull., 30, 347 (1995)

19. J. Guan, S. E. Dorris, U. Balachandran, and M. Liu, Solid State Ionics, 100, 45 (1997)

20. J. Guan, S. E. Dorris, U. Balachandran, and M. Liu, Solid State Ionics, Submitted.

21. T. Setoguchi, K. Okamoto, K. Eguchi, and H. Arai, $J$. Electrochem. Soc, 139, 2875 (1992).

22. K. Kreuer, E. Schönherr, and J. Maier, in Proceedings of the 14th Risø International Symposium on Materials Science, p. 193, Risø National Laboratory, Roskilde, Denmark (1993)

23. A. S. Nowick and Y. Du, Solid State Ionics, 77, 137 (1995).

24. D. Shima and S. M. Haile, Solid State Ionics, 97, 443 (1997).

25. I. Kosacki and H. Anderson, Appl. Phys. Lett., 69, 4171 (1996).

26. M. Liu and D. Wang, J. Mater. Res., 10, 3210 (1995).

27. Y. Du and A. S. Nowick, J. Am. Ceram. Soc., 78, 3033 (1995).

28. F. Kulcsar, J. Am. Ceram. Soc., 39, 13 (1956)

29. S. Witek and D. M. Smith, J. Am. Ceram. Soc., 67, 372 (1984).

30. C. Lu and L. C. De Jonghe, J. Am. Ceram. Soc., 77, 2523 (1994).

31. V. Agarwal and M. Liu, J. Electrochem. Soc., 144, 1035 (1997).

32. F. S. Galasso, Structure, Properties, and Preparation of Perovskite-type Compounds, Pergamon Press, Oxford, England (1969).

\title{
Determination of the Trap Density in Amorphous Silicon by Quasi-Static Capacitance-Voltage Measurements
}

\author{
W. R. Fahrner* and S. Löffler ${ }^{a}$ \\ Department of Electrical Engineering, University of Hagen, D-58084 Hagen, Germany \\ Y. Chan, S. Kwong, and K. Man \\ City University of Hong Kong, Kowloon, Hong Kong
}

\section{ABSTRACT}

A special metal-oxide-semiconductor structure based on hydrogenated amorphous silicon has been fabricated. The quasi-static capacitance-voltage (CV) curves of this device are calculated for various trap densities of the amorphous silicon. Due to the occurrence of punch-through. Poisson's equation cannot be solved analytically. Thus, a finite elements approach has been used to compute the potential distribution and the charge density in the semiconductor. Differentiation of the charge with respect to the applied voltage delivers the low-frequency CV curve. In the last step, this CV curve is fitted to a measured one in order to determine the trap density. We find a trap density of $N_{\mathrm{b} 0}=9 \cdot 10^{16} \mathrm{~V}^{-1} \mathrm{~cm}^{-3}$ at midgap.

\section{Introduction}

Amorphous silicon (a-Si) is a material widely used in thin film transistors (TFTs) and solar cells. In a large scale manufacturing process routine control is desirable. With respect to the above applications, the control should be based on electrical measurements. The a-Si characterization, however, involves optical methods to a large extent. This is especially true for a characteristic material parameter, namely, the bulk trap density, $N_{\mathrm{b}}$. It is the purpose of this work to deliver an electrical measurement method for $N_{\mathrm{b}}$.

* Electrochemical Society Active Member

a Present address: Siemens AG, Burlington, VT, USA
In this method a specially designed metal-oxide-a-Si structure is used ${ }^{1}$ and its CV curve is recorded. CV techniques are known from monocrystalline silicon MOS capacitance measurements where they are among the major diagnostic tools used to investigate trap properties. There is a big difference, however, between monocrystalline and amorphous metal-oxide-semiconductor (MOS) structures: in the monocrystalline case, the $\mathrm{CV}$ characteristics are controlled by surface states (the bulk states being negligible), while for amorphous silicon, the CV characteristics are controlled by the bulk states (the surface states being negligible). Among the first to report on this observation were 